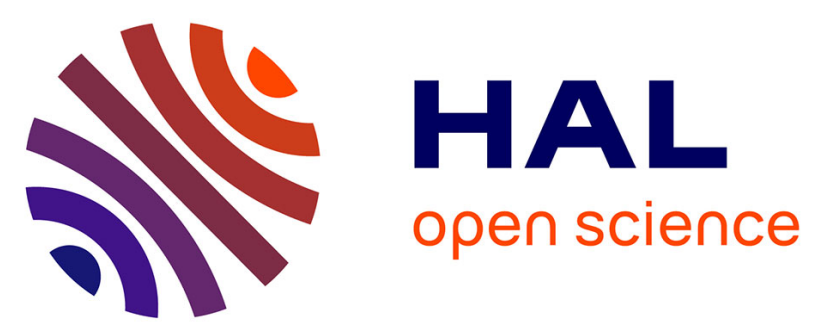

\title{
Modifications of the chemical structure of phenolics differentially affect physiological activities in pulvinar cells of Mimosa pudica L. I. Multimode effect on early membrane events
}

Francoise Rocher, Fabienne Dédaldéchamp, Saed Saeedi, Pierrette

Fleurat-Lessard, Jean-François Chollet, Gabriel Roblin

\section{To cite this version:}

Francoise Rocher, Fabienne Dédaldéchamp, Saed Saeedi, Pierrette Fleurat-Lessard, Jean-François Chollet, et al.. Modifications of the chemical structure of phenolics differentially affect physiological activities in pulvinar cells of Mimosa pudica L. I. Multimode effect on early membrane events. Plant Physiology and Biochemistry, 2014, 84, pp.240-250. 10.1016/j.plaphy.2014.09.020 . hal-02165837

\section{HAL Id: hal-02165837 \\ https://hal.science/hal-02165837}

Submitted on 26 Jun 2019

HAL is a multi-disciplinary open access archive for the deposit and dissemination of scientific research documents, whether they are published or not. The documents may come from teaching and research institutions in France or abroad, or from public or private research centers.
L'archive ouverte pluridisciplinaire HAL, est destinée au dépôt et à la diffusion de documents scientifiques de niveau recherche, publiés ou non, émanant des établissements d'enseignement et de recherche français ou étrangers, des laboratoires publics ou privés. 


\section{Modifications of the chemical structure of phenolics differentially affect physiological activities in pulvinar cells of Mimosa pudica $\mathbf{L}$. I. Multimode effect on early membrane events}

Françoise Rocher ${ }^{1}$, Fabienne Dédaldéchamp ${ }^{2} *$, Saed Saeedi ${ }^{2}$, Pierrette FleuratLessard $^{2}$, Jean-Francois Chollet ${ }^{1}$, Gabriel Roblin ${ }^{2}$

${ }^{1}$ IC2MP (Institut de Chimie des Milieux et des Matériaux de Poitiers), UMR CNRS 7285, Université de Poitiers, 4 rue Michel Brunet, TSA 51106, F-86073 Poitiers cedex 9, France

${ }^{2}$ Laboratoire EBI (Écologie et Biologie des Interactions), UMR CNRS 7267, Équipe SEVE (Sucres, Échanges Végétaux, Environnement), Université de Poitiers, 3 rue Jacques Fort, TSA 51106, F-86073 Poitiers cedex 9, France

* Corresponding author. Tel.: +33 5494537 60; fax: +33 549454185

E-mail address: fabienne.dedaldechamp@univ-poitiers.fr (F. Dédaldéchamp) 


\begin{abstract}
A study of the structure-activity relationship carried out on several benzoic acidrelated phenolics indicates that this type of compounds hinders the osmocontractile reaction of pulvinar cells in the range of $0-100 \%$. Tentatively, we tried to find a way that could explain this differential action. With this aim, the relationship between the inhibitory effect and important molecular physico-chemical parameters (namely lipophilicity and degree of dissociation) was drawn. In addition, the effect of a variety of these compounds was investigated on their capacity to modify the electrical transmembrane potential and induce modifications in proton fluxes. Finally, using plasma membrane vesicles purified from pulvinar tissues, we examined the effects of some selected compounds on the proton pump activity and catalytic activity of the plasma membrane $\mathrm{H}^{+}$-ATPase. Taken together, the results indicate that a modification of the molecular structure of phenolics may induce important variation in the activity of the compound on these early membrane events. Among the tested phenolics, salicylic acid (SA) and acetylsalicylic acid (ASA, aspirin) are of particuler note, as they showed atypical effects on the physiological processes studied.
\end{abstract}

Keywords: Aspirin, Salicylic acid, $\mathrm{H}^{+}$-ATPase, Membrane potential, Mimosa pudica, Phenolics, Seismonasty 


\section{Introduction}

Phenolic compounds, ubiquitously present in the plant kingdom, fulfill a broad range of physiological roles, either by playing cell wall structural roles or by their implication in plant growth and survival (Cheynier et al., 2013). The accumulation of phenolic compounds in plant organs is a widespread consequence of either biotic or abiotic stresses and participates in the survival and adaptation of plants to environmental disturbances (Lattanzio et al., 2009). Phenolic compounds have been the subject of extensive research regarding their effects on various processes governing plant growth and development. These investigations have particularly been carried out in the general scope of allelopathy in order to tentatively describe the chemical interaction between plants. Indeed, phenolics synthesized in plants may be delivered into the rhizosphere through leaching from leaves, by root exudation and by the breakdown of bark and leaf litter (Bertin et al., 2003). Phenolics have been shown to be multisite effectors through their action on a variety of important cellular processes. Thus, they have been documented to influence membrane permeability, nutrient uptake, photosynthesis and respiration, as well as the activities of many enzymes (such as catalase and peroxidase, phenylalanine ammonia lyase, phosphorylase, aldolase, pyruvate kinase and glucose phosphate isomerase) and protein synthesis (Rice, 1984; Muscolo et al., 2001; Weir et al., 2004; Li et al., 2010; references therein). In addition, they have been shown to intervene in the resistance mechanisms of healthy plants and in the defense reaction against pathogens (Harborne, 1980). Thus, it has been observed that benzoic acid (BA) derivatives stimulated pathogenesis-related (PR) proteins in Nicotiana tabacum (Abad et al., 1988) and also triggered the formation of reactive oxygen species (ROS) (Kawano et al., 1998). Furthermore, it appeared that the degree of efficiency of the molecules was related to their chemical structure. From these studies, salicylic acid (SA) has emerged as a pivotal phytohormone and signaling molecule regulating many developmental processes (Raskin, 1992; Vlot et al., 2009).

As previously reported with regards to the effects of SA on various biological reactions in pulvinar cells (Saeedi et al., 2013), a small modification in the molecular arrangement, particularly the presence and position of the hydroxyl group on the benzene ring, dramatically modifies the activity of the molecule. This observation has been extended to a number of BA derivatives in order to determine the structural molecular characteristics which may confer this biological activity. Our experiment was focused on the effects of phenolics of the classes $\mathrm{C}_{6}-\mathrm{C}_{1}, \mathrm{C}_{6}-\mathrm{C}_{2}$ and $\mathrm{C}_{6}-\mathrm{C}_{3}$ (characterized on the basis of their basic skeletons according to (Harborne, 1980), which have been recognized to be a variety of allelochemicals (Rice, 1984). 
The model of the pulvinar cell of Mimosa pudica primary pulvinus was chosen because of its convenience to study the action of externally applied compounds on early induced physiological events. Indeed, the coordinated contraction of the motor cells results in a rapid movement (achieved in about $2 \mathrm{~s}$ ) in response to an excitation of putative mechanoreceptor cells, presence of which has been shown in tertiary pulvini (Visnovitz et al., 2007). In addition, the model allows to precise whether the treatment may modify the ionic fluxes $\left(\mathrm{K}^{+}, \mathrm{Cl}^{-}\right)$driving the osmocontractile reaction (Samejima and Sibaoka, 1980) and the activity of the plasma membrane $\mathrm{H}^{+}$-ATPase involved in the functioning of the motor cells (Fleurat-Lessard et al., 1997; Moran, 2007).

More particularly, the observed effects on the seismonastic osmocontractile pulvinar reaction, the transmembrane cell potential and the secretion of protons by pulvinar cells have been analyzed in correlation with physico-chemical parameters representing the liposolubility $(\log \mathrm{D})$ and the percentage of the non-dissociated form (NDF) of the compound.

\section{Materials and Methods}

\subsection{Plant growth conditions}

Seeds of Mimosa pudica L. were germinated in an organic compost. Seedlings and older plants were grown in this compost watered daily and kept in climate-controlled chambers at $27.5 \pm 0.5^{\circ} \mathrm{C}$ and $65 \pm 5 \%$ relative humidity. Illumination was regulated to give $16 \mathrm{~h}$ of light (photophase 06.00 hours-22.00 hours) provided by fluorescent tubes (mixing Osram fluora and Osram day-light types) with a photon fluence rate (400-700 nm) of 80 $\mu \mathrm{mol} \mathrm{m} \mathrm{s}^{-1}$ at the plant apex.

\subsection{Experimental procedure for observation of seismonastic reaction of the pulvinus model}

Seedlings of $M$. pudica bearing the first fully developed leaf constituted the experimental model for the observation of the seismonastic motor reaction and were prepared as reported in detail previously (Saeedi et al., 2013). The phenolics, dissolved in a medium buffered with $2.5 \mathrm{mM}$ MES at $\mathrm{pH}$ 5.2, were applied through cut hypocotyls dipped in small plastic tubes. Leaf position was determined by measuring the angle formed by the petiole and the line prolonging the hypocotyl by means of a transparent protractor provided with a movable pointer. After measurement of the initial angle ( $\alpha$ ), the pulvini were stimulated by a touch applied on the abaxial half of the organ for $4 \mathrm{~h}$ at 1-h intervals. The motor reaction was monitored by measuring the variation of the angle within $10 \mathrm{~s}$ after the stimulation (See Fig. 1 in supplementary data). The experiments were carried out on 30 seedlings separated in 3 sets. 


\subsection{Measurement of $p H$ variations}

In order to observe $\mathrm{H}^{+}$excretion, primary pulvini $(400 \mathrm{mg}$ ) were excised at $10.00 \mathrm{~h}$ on 2-month old plants bearing generally 10 leaves. The organs were divided in transverse sections and treated following the same procedure previously described (Amborabé et al., 2008): incubation medium composed of $0.50 \mathrm{mM} \mathrm{CaCl}_{2}, 0.25 \mathrm{mM} \mathrm{MgCl}_{2}$, variations of $\mathrm{pH}$ read on a $\mathrm{pH}$-meter provided with combined electrodes (Futura micro-combination, Beckman Coulter) and linked to a potentiometric recorder. Compounds were added as indicated in the figures. In order to quantify the amount of mobilized protons, titration was made $2 \mathrm{~h}$ after the application of the compounds on $2 \mathrm{ml}$ of the incubation medium with $\mathrm{NaOH}$ or $\mathrm{HCl}$ at $5.10^{-3} \mathrm{~N}$. The net proton influx induced by the phenolics was calculated by the difference of proton efflux noted in control and the remaining proton efflux noted after application of the phenolics. The experiments were repeated at least 3 times.

\subsection{Electrophysiological measurements}

A major advantage of the pulvinus model in electrophysiological assays is linked to its size allowing easy handling and also to its particular anatomy characterized by many layers of parenchyma cells surrounding the central cylinder, insuring therefore impalement of a microelectrode in a well-defined kind of cell. The transmembrane potential was measured by the classical electrophysiological method using microelectrodes (tip diameter $<1 \mu \mathrm{m}$, tip resistance from 5 to $30 \mathrm{M} \Omega$ ). For details, see (Amborabé et al., 2008). Briefly, leaf was excised from the stem and pulvinus fixed to the bottom of a $4 \mathrm{ml}$ plexiglas chamber filled with a buffered medium (10 mM MES/ $\mathrm{NaOH}, \mathrm{pH} 5.2)$ containing $1 \mathrm{mM} \mathrm{NaCl}, 0.1 \mathrm{mM} \mathrm{KCl}$, and $0.1 \mathrm{mM} \mathrm{CaCl}_{2}$ (Abe, 1981). The glass microelectrode was impaled into a motor cell of the abaxial ("extensor") half of the organ. Under these conditions, the resting transmembrane potential $\left(\Psi_{0}\right)$ was in the range of -100 to $-150 \mathrm{mV}$. The assays in which $\Psi_{0}$ was out of the range $-110 /-130 \mathrm{mV}$ were discarded since amplitude of the induced electrophysiological modifications may be modulated by the initial resting potential value. Thus, the calculated value from 189 assays was $-121+2 \mathrm{mV}$ (SEM).

\subsection{Preparation and use of PMVs}

Purified PMVs were prepared by phase partitioning of microsomal fractions from the primary pulvini of M. pudica according to (Lemoine et al., 1991) with some minor modifications. PMVs were frozen in liquid nitrogen and stored at $-80{ }^{\circ} \mathrm{C}$. They were put in the inside-out configuration by adding $0.05 \%$ brij-58 in the assay medium (Vianello et al., 1982). Proton pumping and ATPase activity were measured as described in Noubhani et al., (1996) with some minor modifications (Amborabé et al., 2008). ATPase hydrolysis activity of the PMVs was determined by the phosphate released from ATP by the method of Ames 
(1966) in a medium containing $3 \mathrm{mM} \mathrm{MgSO} 4,100 \mathrm{mM} \mathrm{KCl}, 50 \mathrm{mM}$ MES/TRIS (pH 6.5), 3 $\mathrm{mM}$ ATP, $250 \mathrm{mM}$ sucrose, and $40 \mu \mathrm{g}$ of protein. After 5, 10, 45 and $20 \mathrm{~min}, 100 \mu 1$ aliquots were sampled and mixed with the molybdate reagent which stops the reaction. In the 6 batches of vesicles used in this work, treatment with the plasma membrane $\mathrm{H}^{+}$-ATPase inhibitor sodium orthovanadate at $0.25 \mathrm{mM}$ showed that about $60 \%$ of the enzyme activity can be attributed to plasma membrane functioning. Proton pumping activity was monitored as the decrease of 9-aminoacridine absorbance at $495 \mathrm{~nm}$ in a medium buffered with $10 \mathrm{mM}$ MES/TRIS at $\mathrm{pH} 6.5$, containing $50 \mathrm{mM} \mathrm{KCl,} 3 \mathrm{mM} \mathrm{ATP,} 1 \mathrm{mM}$ dithiothreitol, $1 \mathrm{mg}$ bovine serum albumin, $20 \mu \mathrm{M}$ acridine orange, $5 \mathrm{mM}$ valinomycin, $300 \mathrm{mM}$ sorbitol and $75 \mu \mathrm{g}$ of protein in a final volume of $1 \mathrm{ml}$. The reaction was started by addition of $3 \mathrm{mM} \mathrm{MgSO}_{4}$ into the medium.

\subsection{Octanol-water partition coefficient ( $\log D)$}

$\log \mathrm{D}$ is defined as the effective partitioning of all ionic forms of a compound present in equilibrium at a specific $\mathrm{pH}$ in octanol-water mixture (Chollet et al., 2005; Rocher et al., 2006; Rocher et al., 2009). This calculation takes into account the degree of dissociation of the molecule, giving therefore a better representation than $\log \mathrm{P}$ found in the literature (Leo et al., 1971). The given values have been calculated with ACD $\log$ D Suite v.12.01 program (Advanced Chemistry Development, Toronto) for a $\mathrm{pH}$ value of 5.2 to fit our experimental conditions.

\subsection{Chemicals}

All chemicals were purchased from Sigma-Aldrich Chimie SarL, France. The phenolics were prepared in stock solutions at $100 \mathrm{mM}$ in absolute ethanol and used at a maximal final concentration of $1 \mathrm{mM}$. The compounds were diluted in solutions of $2.5 \mathrm{mM}$ MES and used at a $\mathrm{pH}$ adjusted with $0.1 \mathrm{~N} \mathrm{KOH}$. Control assays have shown that this buffered medium did not affect significantly the shock-induced pulvinar movement. A stock solution of the fungal toxin fusicoccin (FC) prepared at $1 \mathrm{mM}$ was dissolved in methanol (7 $\%$ final concentration). It has been verified that the respective solvent concentration assayed in controls did not affect the processes studied at the final concentration used. The chemical structures and characteristics are given in Table 1.

\subsection{Statistical analysis}

As some variables were not normally distributed, correlation analyses were performed between all available data by using the Spearman rank method. Regression curves and 
coefficients of determination $\left(\mathrm{R}^{2}\right)$ were calculated using XLStat v. 2014.3.01 as an add-in for Microsoft Excel v. 14.3.6 running in a Mac OS 10.7.5 environment.

\section{Results}

\subsection{Effects of phenolics on the shock-induced osmocontractile reaction of M. pudica pulvini}

\subsubsection{Chemical structure-activity relationship}

3.1.1.1. Effects of SA derivatives obtained by substitution of various radicals on the benzene ring of $S A$

The data in Fig. 1A show that SA (Table 1, no.1) strongly inhibited the pulvinar osmocontractile reaction by $93 \%$. The addition of a supplementary hydroxyl group in the other positions on the benzene ring (Table 1, nos. 2-5) suppressed the inhibitory efficiency of the molecule (respectively, by 15, 15, 0 and $3 \%$ inhibition). Similarly, the addition of two supplementary hydroxyl groups did not significantly improve the effectiveness (Table 1, nos. $10-11$; respectively by 2 and $4 \%$ inhibition). The addition of a methoxy- or chlorine in the 3 position (Table 1, nos. 6-7) resulted in a very significant hindering of the motile reaction (65\%). Molecules bearing chlorine at the 5-position (Table 1, no. 9) were less active on their own (43\% inhibition) but had their action reinforced when a chlorine was added to the 3position (Table 1, no. 12; 63\% inhibition). Interestingly, the 4-chloro derivative (Table 1, no. 8 ) almost completely inhibited $(87 \%)$ the reaction in a similar manner to SA.

\subsubsection{Effects of derivatives obtained through substitution of the 2-hydroxyl group}

The data in Fig. 1B emphasize, first, both the importance and specificity of an orthohydroxylation on the benzene ring. Indeed, substitution of the hydroxyl group by methoxy, acetyl, amino and nitro groups (Table 1, nos. 14, 16, 17, 18) strongly diminishes the efficiency, inhibiting the reaction by, respectively $38,22,12$ and $33 \%$. In contrast, aspirin (the acetoxy derivative, (Table 1, no. 15) induced a strong inhibition (87\%) of the pulvinar reaction. Secondly, the data indicate the great biological activity given by the introduction of halogenates on the ring (Table 1, nos. 19-26). Thus, following a substitution in position 2 , apart from moderate inhibition (38\%) of the fluoro-derivative (Table 1, no. 19), the chloro-, bromo- and iodo-derivatives (Table 1, nos. 20, 21, 22) were very efficient (respectively 92, 75 and 95\% inhibition). The addition of a second chlorine atom at position 3, 4 and 5 (Table 1 , nos. $23,24,25$ ) did not modify the efficiency (respectively, 92, 93, 92\%); in contrast, the addition of a chlorine atom at position 6 (Table 1, no. 26) that reduced this inhibition (62\%). Note the particular action of TIBA, which acted at very low concentrations $\left(100 \%\right.$ at $10^{-4} \mathrm{M}$; Table 1, no 27), as reported previously (Saeedi et al., 1988). 
3.1.1.3. Effects of benzoic acid derivatives obtained by the substitution of various groups on the benzene ring

In this set of experiments (Fig. 1C), the 2-position on the aromatic ring was occupied by a hydrogen atom and substitutions were made on other positions. Compared to SA, BA (Table 1, no. 28 ) is much less efficient (30\% inhibition) and derivatives obtained through hydroxylation in the meta- and para- positions (Table 1, nos. 29, 30) had no inhibitory effect at all. A similar lack of efficiency was obtained with derivatives bearing two hydroxyl groups (Table 1 , nos. 35,36$)$ and only a small effect $(12 \%$ inhibition) was observed with the tri-hydroxylated derivative (Table 1, no. 41). The introduction of a methoxy-group in position 3 on the ring (Table 1, nos. 31, 37) resulted in moderate inhibition (respectively, 33 and 28\%), which was even further reduced when the methoxy-group (Table 1, nos. 32, 38) was in position 4 (respectively, 3 and 10\%). Noticeably, a large inhibitory effect was again induced with the chlorinated compounds (Table 1 nos. 33, 34, 39, 40) (respectively, 87, 85, 70 and $90 \%$ ).

\subsubsection{Effects of modifications on the aliphatic chain bearing the carboxylic acid function}

The data indicate that a modification of the carboxylic acid function may disturb the biological activity of the original structure (Fig. 1D). Indeed, both salicylaldehyde (Table 1, no. 42) and salicylamide (Table 1, no. 43) only inhibited reactions by $67 \%$ and $60 \%$, respectively. Interestingly, SHAM, an inhibitor of the alternative respiratory pathway, inhibited the motile reaction to a moderate extent (30\% inhibition). Increasing the length of the carbon chain bearing the carboxylic acid function (Table 1, nos. $45,46,47$ ) resulted in an increase of the efficiency of the molecule (respectively, 78, 52 and 90\%) compared to the activity of the BA molecule. The introduction of a double bond in the aliphatic carbon chain (cinnamic acid) did not induce any subsequent effect (compare Table 1, nos. 46 and 48), but the additional substitution of a hydroxyl group in various positions (Table 1, nos. 49, 50 and 51 ) on the benzene ring lowered the inhibitory effect (respectively, 31, 30, 28\%). The substitution by an additional hydroxyl- and methoxy- group (Table 1, nos. 52, 53) resulted in an increased loss of efficiency (respectively, 17 and 4\% inhibition). Interestingly, catechol (a degradation product of SA molecule, Table 1, no. 56) showed no significant effect $(5 \%$ inhibition).

3.1.2. Relationship structure-activity by considering lipophilicity and the dissociation constant of the compounds

3.1.2.1. Relationship between biological activity and octanol-water partition coefficient $(\log D)$ of the molecule 
Molecular lipophilicity of a compound, usually quantified as $\log \mathrm{P}\left(\right.$ or $\log \mathrm{K}_{\mathrm{ow}}$ ), is the partition coefficient between water and n-octanol; the properties of the latter are regarded as similar to those of lipid bilayer membranes. This criterion has made it one of the most commonly reported physico-chemical properties for drugs and pesticides (Leo et al., 1971), allowing a forecast of the ability of a compound to cross through a biological membrane and, consequently, to give insight into the uptake capacity of the product into plant cells. The log $\mathrm{P}$ value can be calculated only for neutral compounds and for ionizable molecules such as carboxylic acids, their partition between water and n-octanol becomes $\mathrm{pH}$-dependent and the distribution coefficient $\log \mathrm{D}$ must be used (Chollet et al., 2005; Bhal et al., 2007; Rocher et al., 2009).

Table 1 reports the calculated values of $\log \mathrm{D}$, a parameter quantifying the liposolubility of the molecule taking into account the experimental $\mathrm{pH}$ (5.2). The relationship between the biological activity and the octanol-water partition coefficient of the tested molecules is shown in Fig. 2. There is strong evidence that the biological inhibitory effect of the compound increased in most cases with increasing $\log$ D. Considered as a whole, however, the correlation linking the two variables appeared to be low (see Table 4). Nevertheless, by considering the discrepancies noted for some compounds, three areas can be distinguished in the representation. The area (A) delimited by the regression straight line (least squares line) $\pm 10 \%$ regroups most of the compounds (26 out of 54). In area (B), several compounds (18 out of 54) showed a higher efficiency than expected. These mainly included benzene rings bearing a radical in position 2, in particular halogens (Table 1, nos. 7, $8,20,21,22,23,24,25,26$ ). It should be stressed that SA and ASA (Table 1, nos. 1, 15) were distinctly found in this area. In contrast, a series of compounds ( 9 out of 54) was less active than expected (area $\mathrm{C}$ ) and was characterized by a radical in position 3 and/or 4 on the benzene ring (Table 1, nos. 13, 29, 30, 32, 35, 38, 53).

\subsubsection{Relationship between biological activity and the dissociation status of the molecule}

Most of the tested phenolics are weak acids which are in equilibrium with their anionic form, this dissociation being characterized in water by the logarithmic dissociation constant $\mathrm{pKa}$. The percentage of neutral form at the $\mathrm{pH}$ used in the experiments (5.2) is given in Table 1.

No correlation has been found between the inhibitory effect on the plant reaction and the dissociation of the molecule. Indeed, data representing the inhibition of the seismonastic reaction as a function of the amount of the neutral form were dispersed uniformly in the diagram (data not shown), and the global statistical analysis found no significant correlation between the two variables (see Table 4). This result indicates that the impact of the 
compound to inhibit plant response is not closely related to the availability of its neutral form, which is preferentially absorbed by plant cells in an acid trap mechanism.

\subsection{Effects of various phenolics on the bioelectrical membrane potential}

Considering the previous data, we tried to assess whether the effect of the compounds on a complex process such as pulvinar shrinkage may possibly be linked to a particular physiological step intervening in the reaction chain leading to the pulvinar reaction. We have previously shown that the membrane potential of the motor cell was modified very early following the application of SA (Saeedi et al., 2013). Therefore, we selected some derivatives in the areas (a), (b), and (c) evidenced previously in Fig. 2 to monitor their actions on this early membrane effect.

Fig. 3 shows examples of the time courses of observed membrane potential variations that complement the example reported previously on SA, BA and $m$ - and $p$-derivatives (Saeedi et al., 2013). Like SA, some compounds such as ASA and cinnamic acid (Table 1, nos. 15,48$)$ strongly hyperpolarized the membrane potential, whereas others such as gallic acid (Table 1, no. 41) had only a feeble effect or induced a depolarization (ferulic acid, Table 1, no. 53). Note that 2,4-dichloro BA (Table 1, no. 24) showed a particular pattern, since, after a low hyperpolarization lasting $5 \mathrm{~min}$, it induced a strong depolarization lasting for $1 \mathrm{~h}$. The addition of FC (known to hyperpolarize the membrane potential) at the end of the assay validated the observed bioelectrical variation.

Table 2 reports the extended data concerning the modification of the membrane potential of the pulvinar cell following application of various phenolics. The majority of compounds used at a final concentration of $1 \mathrm{mM}$ induced a hyperpolarization of the membrane potential (27 out of 35) in a large spectrum of amplitudes, whereas the others induced no response or a depolarization. This bioelectrical variation was very rapid (latency period ranging in most cases from 15 to $60 \mathrm{~s}$ ) and lasted for more than $90 \mathrm{~min}$ in the conditions used.

The data representing the potential variation as a function of $\log \mathrm{D}$ and the amount of the neutral form were dispersed uniformly in the diagrams and no distinct population was distinguished. The statistical analysis found no significant correlation between the variables (see Table 4).

Taken together, these data suggest that the variation of $\Delta \Psi$ is not linked to the physico-chemical properties considered here representing the lipophilicity and the degree of dissociation.

3.3. Effects of phenolics on proton fluxes in pulvinar tissues and on $H^{+}$-ATPase activity of PMVs from the pulvinar tissues 
We have previously reported that the spontaneous acidification monitored in the incubation medium of pulvinar tissues, resulting from the $\mathrm{H}^{+}$-ATPase activity (Amborabé et al., 2008), was inhibited by SA and BA derivatives as a result of their protonophore action (Saeedi et al., 2013) or on the proton flux sustained by the plasma membrane $\mathrm{H}^{+}$-ATPase present in the motor cell (Fleurat-Lessard et al., 1997).

Fig. 4A shows examples of the time courses of $\mathrm{pH}$ variations monitored in the bathing medium of pulvinar tissues incubated in presence of various phenolics. In most cases, the phenolics either diminished the large proton excretion observed in control sets (example of isovanillic acid, Table 2, no. 38) or, similarly to SA (Table 1, no. 1), induced proton absorption, as indicated by the $\mathrm{pH}$ rise monitored in the bathing medium (example of cinnamic acid, Table 2, no. 48). It should be stressed that the case of acetylsalicylic acid (aspirin, Table 2, no. 15) is very noteworthy because it strongly and rapidly induced acidification of the bathing medium (Fig. 5B). Note also that 2,4-dichlorobenzoic acid, (Table 2, no. 24) which triggered a particular response of $\Delta \Psi$, also induced a hindering of proton excretion.

Data in Table 2 show that the modification of $\mathrm{pH}$ monitored in the bathing medium of plant tissues began in most cases after a latency period ranging from 10 to $30 \mathrm{~min}$.

The statistical analysis in Table 4 evidenced that the proton flux is correlated with log D and the extent of the non-dissociated form of the molecule. More precisely, as shown in Fig. 4B, the higher the value of $\log \mathrm{D}$ and NDF, the higher the net $\mathrm{H}^{+}$flux. However, two populations were described by two regression lines presenting a high correlation coefficient. Noteworthy, the upper curve mostly described the compounds in which the position 2 on the ring was occupied by a hydroxyl group or a halogen atom. The cinnamic derivatives were also found in this area. On the lower curve, the compounds with substitutions in position 3 or/and 4 on the ring were found. Note that SA and ASA are characteristic outliers.

Similarly, a relationship appears to link the proton flux and the percentage of the neutral form (Fig. 4C). However, this relationship is complex since three populations can be distinguished. The efficiency of the compounds was given by identical substitutions found in the relation with $\log \mathrm{D}$, as indicated above.

These data indicate that $\mathrm{H}^{+}$flux may be linked to the uptake of the molecule through the acid trap mechanism, but the two physico-chemical criteria considered are not completely satisfactory to explain the process.

In order to verify whether the $\mathrm{H}^{+}$fluxes may be related to the activity of the plasma membrane $\mathrm{H}^{+}$-ATPase, additional assays were carried out on plasma membrane vesicles prepared from pulvinar tissues. This model allows for the examination of a membrane effect without interference in metabolism. The data showed that the effect of the phenolics at this level may present different behaviors (Table 3). The application of the compounds may only 
trigger a protonophore effect (Table 2, nos. 1, 5, 28, 33, 48) or may affect both components of the $\mathrm{H}^{+}$-ATPase activity (Table 2, nos. $2,15,20,41$ ), but with a lower efficiency than that of vanadate, a classical inhibitor of the enzyme. Some compounds only showed a very limited effect on the enzyme activity (Table 2, nos. 29, 30).

\subsection{Relationship between the studied physiological events}

\subsubsection{Relationship between seismonasty, $\Delta \Psi$ and $H^{+}$fluxes}

The statistical analysis in Table 4 clearly evidenced that a strong correlation exists between the inhibition of the seismonastic reaction and the induced potential variation. The larger the induced hyperpolarization was, the more intense the inhibition of the movement. This relationship, however, appears complex and can be described by two linear representations, as shown in Fig. 5A. The regression line (a) was defined from the compounds with several substitutions on the benzene ring, particularly in position 3 or/and 4 .

Similarly, a strong correlation exists between the inhibition of the seismonastic reaction and the net $\mathrm{H}^{+}$influx (Table 4). Fig. 5B shows that the positive correlation between the two variables is also complex and described by two linear correlations. In the linear correlation (a), halogen substitutes and the trihydroxylated compounds were found. Note the particular behavior of 4-hydroxy-3-methoxycinnamic acid (Table 1, no. 53).

\subsubsection{Relationship between the membrane potential variation and the inwardly directed $H^{+}$ flux}

Considered as a whole, the correlation linking the two variables appeared low by considering the $\mathrm{P}$ value (see Table 4). Nevertheless, Fig. 6 shows that in the majority of cases, increased hyperpolarization was linked to an increased inwardly directed $\mathrm{H}^{+}$flux (regression line a). Some particular outliers can be characterized, notably the halogenated compounds (Table 1, nos. 20, 33), ASA (Table 1, no. 15) and hydroxylated substitutes (Table 1, no. 30, 53).

\section{Discussion}

The phenolic compounds disturb different targets into the plant cells as indicated by the comparative data obtained here on various physiological functions in an extent related to the molecular arrangement.

\subsection{Structure-activity relationships}

The main conclusion of the present study by considering the effects of phenolic acids obtained on different processes (namely pulvinar cell osmocontraction, bioelectrical 
membrane potential and proton fluxes) is that the efficiency of the compounds of this chemical family may vary to a large extent according to changes of the molecular structure. This difference in the activity may result from tiny modifications in the molecule arrangement constituted by changes in the nature and/or the position on the benzene ring. This observation has been reported for a long time in a variety of biological models: the uptake of nutrients by the roots (Glass, 1974), the depolarization of roots membrane potential (Glass and Dunlop, 1974; Camusso et al., 2007), the generation of ROS (Kawano et al., 1998), the absorption of ions by barley roots (Glass, 1973), the production of PR proteins in tobacco (Abad et al., 1988), the thermogenesis in inflorescence of Sauromatum guttatum (Raskin et al., 1989), the light-regulated pulvinar reaction of Cassia fasciculata (Saeedi and Roblin, 1987).

The extensive observations of many compounds have allowed some general conclusions. Thus, the 2-position occupied by $-\mathrm{OH},-\mathrm{OCH}_{3}$, or a halogen gave high activity to the molecule. More generally, halogens substituted in other positions on the ring maintained high activity. The carboxylic acid function is also of importance compared to aldehyde and amide. Furthermore, increasing the length of the carbon chain bearing the acid function leads to an increased activity.

\subsection{Early effects at the membrane levels}

A primary effect common in the majority of compounds consisted of the modification observed on the bioelectric potential within a few seconds after application of the compound (Table 2). The triggered hyperpolarization amplitude, which was molecule structuredependent, indicated the modification of ionic fluxes at the plasma membrane level. It can be expected that $\mathrm{K}^{+}$and $\mathrm{Cl}^{-}$are the ionic species that are most likely implicated by considering their involvement as well in the action potential as in the rapid osmocontractile reaction of pulvinar cells (Samejima and Sibaoka, 1980; Abe, 1981). This hypothesis should be sustained by the characterization of the involved ion channel(s). The present electrophysiological data suggest that specific recognition of the compounds at the plasma membrane is likely involved, consequently addressing the question about the as yet unknown presence of a putative receptor in the membrane. In particular, the affinity of a given compound for the receptor has to be considered in function of the structural arrangement as deduced from the data in Table 2. This should be tentatively related to molecular descriptors other than $\Delta \Psi$ and NDF. Indeed, the absence of correlation between $\Delta \Psi$ and log D or NDF indicated that the modification of membrane potential is not linked to molecule absorption.

Nevertheless, the absorption of the compounds may be an important component in a second phase, since the effect of this type of compound on other intracellular compartments 
has been reported, in particular with regard to mitochondria (Polygalova and Ponomareva, 2010; Dédaldéchamp et al., 2014). In consequence of this mitochondrial disturbing, BA derivatives may act as uncouplers with different sensitivity as shown previously (Dédaldéchamp et al., 2014). However, this uncoupling effect does not seem to be essential in the inhibition of early events considering for example the case of 2,3,4-Trihydroxy BA: low effect on seismonastic reaction (Fig. 1), no effect on $\Delta \Psi$, low effect on $\mathrm{H}^{+}$extrusion (Table 2), but an increased $\mathrm{O}_{2}$ consumption (activation of $15 \%$ ) in a similar way as SA (data not shown). This data suggest that the impairment of the energy charge by this way may only intervene in long-term physiological processes.

Furthermore, it has been reported that SA is recognized in cells following binding to a variety of SA-binding proteins, thereby triggering a particular reaction cascade through action on different enzymes (Vlot et al., 2009 and references therein). In this respect, the correlation between the net $\mathrm{H}^{+}$influx and $\log \mathrm{D}$ and NDF suggests that the uptake of the compound is a necessary step to induce proton mobilization, in relation to the liposolubility and the degree of dissociation of the molecule. It should be stressed that the proton fluxes are triggered a relatively long time after the modification of $\Delta \Psi$. The mobilization of protons noted in all compounds tested may be of different origins. At first, the proton flux may result from the protonophore effect of the phenolics, as previously reported (Miyahara and Karler, 1965; Demos et al., 1975; Saeedi et al., 2013). Another possibility would be an effect on the membrane $\mathrm{H}^{+}$-ATPase. In course of the study of the effect of some selected compounds on the activity of the plasma membrane $\mathrm{H}^{+}$-ATPase from purified plasma membrane vesicles, we evidence the multimode effect of the compounds also observed at this level (Table 3). Indeed, some compounds are capable of inhibiting both components of enzyme activity (proton pumping and catalytic activity), whereas other compounds only induced a protonophore effect or were without effect. When efficient, the compounds induced an impairment of the proton motive force, leading to a dysfunction of the plasma membrane and consequently inhibition of the osmocontractile reaction.

\subsection{Particular cases}

In the variety of the compounds tested, particular molecules retain our attention. Compared to the other tested phenolics, SA is distinguished because of its powerful actions on the studied processes and, therefore, it appears frequently in the statistical analyses as an outlier. This suggests that SA acts through specific mechanisms compared to other related phenolics. In particular, extensive studies during the 20 past years have evidenced that SA plays a crucial role in plant defense against pathogens by regulating both local disease resistance mechanism and systemic acquired resistance, through induction of specific gene expression (Vlot et al., 2009 and references therein). The involvement in resistance is not 
shared by the majority of the phenolics tested here. SA has also been considered as a phytohormone intervening in various developmental processes in the entire life of plants (germination, growth, flowering, senescence). In particular, it has been shown that SA communicates with other phytohormones implied in the different processes (auxins, cytokinins, gibberellins, ethylene etc) (Vlot et al., 2009; Rivas-San Vicente and Plasencia, 2011; references therein). However, some BA derivatives have been reported to interact with growth processes (Äberg, 1981) or flowering (Kaihara et al., 1981) so that this aspect appears as not specific for SA.

It is also worth mentioning the atypical effects induced by ASA. Indeed, it inhibited seismonasty, induced hyperpolarization of the membrane, but very rapidly activated proton excretion, which is contradictory with its inhibiting effect on both components of the $\mathrm{H}^{+}$ATPase. However, ASA induces an increased $\mathrm{O}_{2}$ consumption (activation of $12 \%$ ) in a similar way as SA (data not shown). Therefore, the determination of the mode of action of this compound needs a specific study.

\subsection{To conclude}

The macroscopic effects of phenolic acids may be achieved by activation of different reaction chains, but a pivotal role may be assigned to the modification induced at the plasma membrane level. The signal linked to the membrane potential modification appears to direct the physiological changes thereafter as argued by the correlation between $\Delta \Psi$ and the proton flux, and, consequently, inhibition of the osmocontractile reaction resulting from a complex succession of biochemical events.

The bioelectrical effect at the membrane level appears to be a pivotal step in the signaling chain since comparison with the data reported in a previous work (Amborabé et al., 2002) concerning the growth inhibition of a fungal pathogen evidenced that a lot of phenolic compounds are found in the same respective areas $(a, b, c)$ of Fig. 2, as well in a rapid phenomenon such as seismonasty (observed in minutes) as in a developmental process (in days). Forty-six compounds were tested both for growth inhibition of Eutypa lata and inhibition of the seismonastic reaction in Mimosa pudica. The Spearman correlation coefficient between the two measures was 0.566 with a p-value $<0.0001$. The most striking point is that among the nine products that inhibit the growth of Eutypa lata by $60 \%$ or more, eight of them (Table 1, nos. 1, 8, 25, 26, 33, 39, 40) inhibited the osmocontractile reaction in Mimosa pudica also with a value greater than $60 \%$. Except SA, all are mono- or dichlorinated derivatives. This observation suggests that the signal linked to the membrane potential modification directs the metabolic changes thereafter.

Although $\log \mathrm{D}$ and percentage of NDF present some important impact on the observed physiological processes, these criteria do not totally explain the variation in activity 
of the different phenolic molecules by considering the various correlations drawn from the statistical analyses. Therefore, studies that are currently in progress are devoted to analyzing the impact of other molecular descriptors on the physiological processes studied in this work.

\section{References}

Abad, P., Marais, A., Cardin, L., Poupet, A., Ponchet, M., 1988. The effect of benzoic acid derivatives on Nicotiana tabacum growth in relation to PR-b1 production. Antiviral Res. 9, 315327.

Abe, T., 1981. Chloride-ion efflux during an action potential in the main pulvinus of Mimosa pudica. Bot. Mag. Tokyo 94, 379-383.

Äberg, B., 1981. Plant growth regulators. XLI. mono substituted benzoic acids. Swed. J. Agric. Res. 11, 93-105.

Amborabé, B.E., Bonmort, J., Fleurat-Lessard, P., Roblin, G., 2008. Early events induced by chitosan on plant cells. J. Exp. Bot. 59, 2317-2324.

Amborabé, B.E., Fleurat-Lessard, P., Chollet, J.F., Roblin, G., 2002. Antifungal effects of salicylic acid and other benzoic acid derivatives towards Eutypa lata: structure-activity relationship. Plant Physiol. Biochem. 40, 1051-1060.

Ames, B.N., 1966. Assay of inorganic phosphate, total phosphate and phosphatases. Methods Enzymol. 8, 115-118.

Bertin, C., Yang, X.H., Weston, L.A., 2003. The role of root exudates and allelochemicals in the rhizosphere. Plant Soil 256, 67-83.

Bhal, S.K., Kassam, K., Peirson, I.G., Pearl, G.M., 2007. The rule of five revisited: Applying $\log \mathrm{D}$ in place of $\log \mathrm{p}$ in drug-likeness filters. Mol. Pharm. 4, 556-560.

Camusso, W., Sacco, S., Maffei, M., Bertea, C.M., 2007. Effect of benzoic acid hydroxyland methoxy-ring substituents on cucumber (Cucumis sativus L.) root membrane potential. J. Plant Interact. 2, 185-193.

Cheynier, V., Comte, G., Davies, K.M., Lattanzio, V., Martens, S., 2013. Plant phenolics: Recent advances on their biosynthesis, genetics, and ecophysiology. Plant Physiol. Biochem. 72, $1-20$.

Chollet, J.F., Rocher, F., Jousse, C., Deletage-Grandon, C., Bashiardes, G., Bonnemain, J.L., 2005. Acidic derivatives of the fungicide fenpiclonil: effect of adding a methyl group to the Nsubstituted chain on systemicity and fungicidal activity. Pest Manag. Sci. 61, 377-382.

Dédaldéchamp, F., Saeedi, S., Fleurat-Lessard, P., Roblin, G., 2014. Uptake and metabolic effects of salicylic acid on the pulvinar motor cells of Mimosa pudica L. Plant Physiol. Biochem. 74, 125-132.

Demos, E.K., Woolwine, M., Wilson, R.H., McMillan, C., 1975. Effects of ten phenolic compounds on hypocotyl growth and mitochondrial metabolism of mung bean. Am. J. Bot. 62, 97-102.

Fleurat-Lessard, P., Bouché-Pillon, S., Leloup, C., Bonnemain, J.L., 1997. Distribution and activity of the plasma membrane $\mathrm{H}+-\mathrm{ATPase}$ in Mimosa pudica $\mathrm{L}$ in relation to ionic fluxes and leaf movements. Plant Physiol. 113, 747-754.

Glass, A.D.M., 1973. Influence of phenolic acids on ion uptake. I. Inhibition of phosphate uptake. Plant Physiol. 51, 1037-1041.

Glass, A.D.M., 1974. Influence of phenolic acids upon ion uptake. III. Inhibition of potassium absorption. J. Exp. Bot. 25, 1104-1113.

Glass, A.D.M., Dunlop, J., 1974. Influence of phenolic acids on ion uptake. IV. Depolarization of membrane potentials. Plant Physiol. 54, 855-858.

Harborne, J.B., 1980. Plant phenolics. In: A. Bell, B. Charlwood (Eds.) Encyclopedia of Plant Physiology. New Series. Volume 8. Secondary plant products, Springer-Verlag, Berlin, Germany, pp. 329-402. 
Kaihara, S., Watanabe, K., Takimoto, A., 1981. Flower-inducing effect of benzoic and salicylic acids in various strains of lemna paucicostata and lemna minor. Plant Cell Physiol. 22, 819-825.

Kawano, T., Sahashi, N., Takahashi, K., Uozumi, N., Muto, S., 1998. Salicylic acid induces extracellular superoxide generation followed by an increase in cytosolic calcium ion in tobacco suspension culture: The earliest events in salicylic acid signal transduction. Plant Cell Physiol. 39, 721-730.

Lattanzio, V., Cardinali, A., Ruta, C., Fortunato, I.M., Lattanzio, V.M.T., Linsalata, V., Cicco, N., 2009. Relationship of secondary metabolism to growth in oregano (Origanum vulgare L.) shoot cultures under nutritional stress. Environ. Exp. Bot. 65, 54-62.

Lemoine, R., Bourquin, S., Delrot, S., 1991. Active uptake of sucrose by plant plasma membrane vesicles: determination of some important physical and energetical parameters. Physiol. Plant. 82, 377-384.

Leo, A., Hansch, C., Elkins, D., 1971. Partition coefficients and their uses. Chem. Rev. 71, 525-616.

Li, Z.H., Wang, Q.A., Ruan, X.A., Pan, C.D., Jiang, D.A., 2010. Phenolics and plant allelopathy. Molecules 15, 8933-8952.

Miyahara, J.T., Karler, R., 1965. Effect of salicylate on oxidative phosphorylation and respiration of mitochondrial fragments. Biochem. J. 97, 194-198.

Moran, N., 2007. Osmoregulation of leaf motor cells. FEBS Lett. 581, 2337-2347.

Muscolo, A., Panuccio, M.R., Sidari, M., 2001. The effect of phenols on respiratory enzymes in seed germination - Respiratory enzyme activities during germination of Pinus laricio seeds treated with phenols extracted from different forest soils. Plant Growth Regul. 35, 31-35.

Noubhani, A.M., Sakr, S., Denis, M.H., Delrot, S., 1996. Transcriptional and posttranslational control of the plant plasma membrane H+-ATPase by mechanical treatments. Biochim. Biophys. Acta 1281, 213-219.

Polygalova, O.O., Ponomareva, A.A., 2010. Protonophores as inducers of energy-dependent changes of ultrastructure of mitochondria in wheat root cells. Cell and Tissue Biology 4, 297-304.

Raskin, I., 1992. Role of salicylic acid in plants. Annu. Rev. Plant Physiol. Plant Mol. Biol. 43, 439-463.

Raskin, I., Turner, I.M., Melander, W.R., 1989. Regulation of heat production in the inflorescences of an Arum lily by endogenous salicyclic acid. Proc. Natl. Acad. Sci. U. S. A. 86, 2214-2218.

Rice, E.L., 1984. Allelopathy, 2nd ed., Academic Press, Orlando.

Rivas-San Vicente, M., Plasencia, J., 2011. Salicylic acid beyond defence: its role in plant growth and development. J. Exp. Bot. 62, 3321-3338.

Rocher, F., Chollet, J.F., Jousse, C., Bonnemain, J.L., 2006. Salicylic acid, an ambimobile molecule exhibiting a high ability to accumulate in the phloem. Plant Physiol. 141, 1684-1693.

Rocher, F., Chollet, J.F., Legros, S., Jousse, C., Lemoine, R., Faucher, M., Bush, D.R., Bonnemain, J.L., 2009. Salicylic acid transport in Ricinus communis involves a pH-dependent carrier system in addition to diffusion. Plant Physiol. 150, 2081-2091.

Saeedi, S., Roblin, G., 1987. Action of benzoic acid and its ortho-hydroxy derivatives, metahydroxy derivatives and para-hydroxy derivatives on the dark-induced and light-induced leaflet movements in Cassia fasciculata michx. Plant Cell Physiol. 28, 1109-1115.

Saeedi, S., Roblin, G., Auger, E., 1988. Effects of 2,3,5-triiodobenzoic acid on seismonastic reaction, respiration, proton fluxes and membrane potential of motor cells in Mimosa pudica pulvinus. Plant Physiol. Biochem. 26, 145-150.

Saeedi, S., Rocher, F., Bonmort, J., Fleurat-Lessard, P., Roblin, G., 2013. Early membrane events induced by salicylic acid in motor cells of the Mimosa pudica pulvinus. J. Exp. Bot. 64, 1829-1836.

Samejima, M., Sibaoka, T., 1980. Changes in the extracellular ion concentration in the main pulvinus of Mimosa pudica during rapid movement and recovery. Plant Cell Physiol. 21, 467-479.

Vianello, A., Dellantone, P., Macri, F., 1982. ATP-dependent and ionophore-induced proton translocation in pea stem microsomal vesicles. Biochim. Biophys. Acta 689, 89-96. 
Visnovitz, T., Világi, I., Varró, P., Kristóf, Z., 2007. Mechanoreceptor cells on the tertiary pulvini of Mimosa pudica L. Plant signaling \& behavior 2, 462-466.

Vlot, A.C., Dempsey, D.A., Klessig, D.F., 2009. Salicylic acid, a multifaceted hormone to combat disease. Annu. Rev. Phytopathol. 47, 177-206.

Weir, T.L., Park, S.W., Vivanco, J.M., 2004. Biochemical and physiological mechanisms mediated by allelochemicals. Curr. Opin. Plant Biol. 7, 472-479. 
Table 1

Structure arrangements of the phenolics used in this study, values of $\log \mathrm{D}$ and $\%$ of neutral form at $\mathrm{pH} 5.2$.<smiles>[2H]c1c([2H])c([2H])c(Br)c([2H])c1[2H]</smiles>

\begin{tabular}{|c|c|c|c|c|c|c|c|c|c|}
\hline $\mathbf{N}^{\circ}$ & Compound & $\mathbf{R}_{1}$ & $\mathbf{R}_{2}$ & $\mathbf{R}_{\mathbf{3}}$ & $\mathbf{R}_{4}$ & $\mathbf{R}_{\mathbf{5}}$ & $\mathbf{R}_{6}$ & $\log D$ & $\begin{array}{l}\% \text { neutral } \\
\text { form }\end{array}$ \\
\hline 1 & Salicylic acid & $\mathrm{COOH}$ & $\mathrm{OH}$ & $\mathrm{H}$ & $\mathrm{H}$ & $\mathrm{H}$ & $\mathrm{H}$ & -0.77 & 8.3 \\
\hline 2 & 2,3-Dihydroxybenzoic acid & $\mathrm{COOH}$ & $\mathrm{OH}$ & $\mathrm{OH}$ & $\mathrm{H}$ & $\mathrm{H}$ & $\mathrm{H}$ & -1.27 & 2.3 \\
\hline 3 & 2,4-Dihydroxybenzoic acid & $\mathrm{COOH}$ & $\mathrm{OH}$ & $\mathrm{H}$ & $\mathrm{OH}$ & $\mathrm{H}$ & $\mathrm{H}$ & -0.90 & 7.6 \\
\hline 4 & 2,5-Dihydroxybenzoic acid & $\mathrm{COOH}$ & $\mathrm{OH}$ & $\mathrm{H}$ & $\mathrm{H}$ & $\mathrm{OH}$ & $\mathrm{H}$ & -1.45 & 1.8 \\
\hline 5 & 2,6-Dihydroxybenzoic acid & $\mathrm{COOH}$ & $\mathrm{OH}$ & $\mathrm{H}$ & $\mathrm{H}$ & $\mathrm{H}$ & $\mathrm{OH}$ & -0.77 & 0.1 \\
\hline 6 & 2-Hydroxy-3-methoxybenzoic acid & $\mathrm{COOH}$ & $\mathrm{OH}$ & $\mathrm{OCH}_{3}$ & $\mathrm{H}$ & $\mathrm{H}$ & $\mathrm{H}$ & -0.96 & 4.7 \\
\hline 7 & 3-Chlorosalicylic acid & $\mathrm{COOH}$ & $\mathrm{OH}$ & $\mathrm{Cl}$ & $\mathrm{H}$ & $\mathrm{H}$ & $\mathrm{H}$ & -0.02 & 13.3 \\
\hline 8 & 4-Chlorosalicylic acid & $\mathrm{COOH}$ & $\mathrm{OH}$ & $\mathrm{H}$ & $\mathrm{Cl}$ & $\mathrm{H}$ & $\mathrm{H}$ & 0.14 & 23.1 \\
\hline 9 & 5-Chlorosalicylic acid & $\mathrm{COOH}$ & $\mathrm{OH}$ & $\mathrm{H}$ & $\mathrm{H}$ & $\mathrm{Cl}$ & $\mathrm{H}$ & 0.23 & 22.0 \\
\hline 10 & 2,3,4-Trihydroxybenzoic acid & $\mathrm{COOH}$ & $\mathrm{OH}$ & $\mathrm{OH}$ & $\mathrm{OH}$ & $\mathrm{H}$ & $\mathrm{H}$ & -1.47 & 2.0 \\
\hline 11 & 2,4,6-Trihydroxybenzoic acid & $\mathrm{COOH}$ & $\mathrm{OH}$ & $\mathrm{H}$ & $\mathrm{OH}$ & $\mathrm{H}$ & $\mathrm{OH}$ & -1.10 & 0.1 \\
\hline 12 & 3,5-Dichlorosalicylic acid & $\mathrm{COOH}$ & $\mathrm{OH}$ & $\mathrm{Cl}$ & $\mathrm{H}$ & $\mathrm{Cl}$ & $\mathrm{H}$ & 1.08 & 11.3 \\
\hline 13 & 3,5,6-Trichlorosalicylic acid & $\mathrm{COOH}$ & $\mathrm{OH}$ & $\mathrm{Cl}$ & $\mathrm{H}$ & $\mathrm{Cl}$ & $\mathrm{Cl}$ & 1.42 & 2.5 \\
\hline 14 & 2-Methoxybenzoic acid & $\mathrm{COOH}$ & $\mathrm{OCH}_{3}$ & $\mathrm{H}$ & $\mathrm{H}$ & $\mathrm{H}$ & $\mathrm{H}$ & 0.16 & 61.4 \\
\hline 15 & Acetylsalicylic acid (Aspirin) & $\mathrm{COOH}$ & $\mathrm{OCOCH}_{3}$ & $\mathrm{H}$ & $\mathrm{H}$ & $\mathrm{H}$ & $\mathrm{H}$ & -0.31 & 32.9 \\
\hline 16 & 2-Acetyl benzoic acid & $\mathrm{COOH}$ & $\mathrm{COCH}_{3}$ & $\mathrm{H}$ & $\mathrm{H}$ & $\mathrm{H}$ & $\mathrm{H}$ & -0.29 & 38.8 \\
\hline 17 & 2-Aminobenzoic acid & $\mathrm{COOH}$ & $\mathrm{NH}_{2}$ & $\mathrm{H}$ & $\mathrm{H}$ & $\mathrm{H}$ & $\mathrm{H}$ & 0.45 & 77.9 \\
\hline 18 & 2-Nitrobenzoic acid & $\mathrm{COOH}$ & $\mathrm{NO}_{2}$ & $\mathrm{H}$ & $\mathrm{H}$ & $\mathrm{H}$ & $\mathrm{H}$ & -1.58 & 1.6 \\
\hline 19 & 2-Fluorobenzoic acid & $\mathrm{COOH}$ & $\mathrm{F}$ & $\mathrm{H}$ & $\mathrm{H}$ & $\mathrm{H}$ & $\mathrm{H}$ & -0.38 & 28.4 \\
\hline 20 & 2-Chlorobenzoic acid & $\mathrm{COOH}$ & $\mathrm{Cl}$ & $\mathrm{H}$ & $\mathrm{H}$ & $\mathrm{H}$ & $\mathrm{H}$ & -0.31 & 29.7 \\
\hline 21 & 2-Bromobenzoic acid & $\mathrm{COOH}$ & $\mathrm{Br}$ & $\mathrm{H}$ & $\mathrm{H}$ & $\mathrm{H}$ & $\mathrm{H}$ & 0.19 & 52.6 \\
\hline 22 & 2-Iodobenzoic acid & $\mathrm{COOH}$ & I & $\mathrm{H}$ & $\mathrm{H}$ & $\mathrm{H}$ & $\mathrm{H}$ & 0.12 & 49.6 \\
\hline 23 & 2,3-Dichlorobenzoic acid & $\mathrm{COOH}$ & $\mathrm{Cl}$ & $\mathrm{Cl}$ & $\mathrm{H}$ & $\mathrm{H}$ & $\mathrm{H}$ & 0.22 & 46.9 \\
\hline 24 & 2,4-Dichlorobenzoic acid & $\mathrm{COOH}$ & $\mathrm{Cl}$ & $\mathrm{H}$ & $\mathrm{Cl}$ & $\mathrm{H}$ & $\mathrm{H}$ & 0.35 & 56.3 \\
\hline 25 & 2,5-Dichlorobenzoic acid & $\mathrm{COOH}$ & $\mathrm{Cl}$ & $\mathrm{H}$ & $\mathrm{H}$ & $\mathrm{Cl}$ & $\mathrm{H}$ & 0.27 & 48.4 \\
\hline 26 & 2,6-Dichlorobenzoic acid & $\mathrm{COOH}$ & $\mathrm{Cl}$ & $\mathrm{H}$ & $\mathrm{H}$ & $\mathrm{H}$ & $\mathrm{Cl}$ & -0.82 & 4.1 \\
\hline 27 & 2,3,5-Triiodobenzoic acid (TIBA) & $\mathrm{COOH}$ & I & I & $\mathrm{H}$ & I & $\mathrm{H}$ & 1.87 & 55.7 \\
\hline 28 & Benzoic acid & $\mathrm{COOH}$ & $\mathrm{H}$ & $\mathrm{H}$ & $\mathrm{H}$ & $\mathrm{H}$ & $\mathrm{H}$ & 0.52 & 78.5 \\
\hline 29 & $m$-Hydroxybenzoic acid & $\mathrm{COOH}$ & $\mathrm{H}$ & $\mathrm{OH}$ & $\mathrm{H}$ & $\mathrm{H}$ & $\mathrm{H}$ & -0.03 & 50.4 \\
\hline 30 & $p$-Hydroxybenzoic acid & $\mathrm{COOH}$ & $\mathrm{H}$ & $\mathrm{H}$ & $\mathrm{OH}$ & $\mathrm{H}$ & $\mathrm{H}$ & 0.58 & 81.8 \\
\hline 31 & 3-Methoxybenzoic acid & $\mathrm{COOH}$ & $\mathrm{H}$ & $\mathrm{OCH}_{3}$ & $\mathrm{H}$ & $\mathrm{H}$ & $\mathrm{H}$ & 0.51 & 77.3 \\
\hline 32 & 4-Methoxybenzoic acid & $\mathrm{COOH}$ & $\mathrm{H}$ & $\mathrm{H}$ & $\mathrm{OCH}_{3}$ & $\mathrm{H}$ & $\mathrm{H}$ & 0.97 & 91.6 \\
\hline 33 & 3-Chlorobenzoic acid & $\mathrm{COOH}$ & $\mathrm{H}$ & $\mathrm{Cl}$ & $\mathrm{H}$ & $\mathrm{H}$ & $\mathrm{H}$ & 1.15 & 92.2 \\
\hline 34 & 4-Chlorobenzoic acid & $\mathrm{COOH}$ & $\mathrm{H}$ & $\mathrm{H}$ & $\mathrm{Cl}$ & $\mathrm{H}$ & $\mathrm{H}$ & 1.23 & 93.6 \\
\hline 35 & 3,4-Dihydroxybenzoic acid & $\mathrm{COOH}$ & $\mathrm{H}$ & $\mathrm{OH}$ & $\mathrm{OH}$ & $\mathrm{H}$ & $\mathrm{H}$ & -0.03 & 52.8 \\
\hline 36 & 3,5-Dihydroxybenzoic acid & $\mathrm{COOH}$ & $\mathrm{H}$ & $\mathrm{OH}$ & $\mathrm{H}$ & $\mathrm{OH}$ & $\mathrm{H}$ & -0.68 & 19.6 \\
\hline 37 & 4-Hydroxy-3-methoxybenzoic acid & $\mathrm{COOH}$ & $\mathrm{H}$ & $\mathrm{OCH}_{3}$ & $\mathrm{OH}$ & $\mathrm{H}$ & $\mathrm{H}$ & 0.38 & 73.5 \\
\hline 38 & 3-Hydroxy-4-methoxybenzoic acid & $\mathrm{COOH}$ & $\mathrm{H}$ & $\mathrm{OH}$ & $\mathrm{OCH}_{3}$ & $\mathrm{H}$ & $\mathrm{H}$ & 0.24 & 66.6 \\
\hline 39 & 3,4-Dichlorobenzoic acid & $\mathrm{COOH}$ & $\mathrm{H}$ & $\mathrm{Cl}$ & $\mathrm{Cl}$ & $\mathrm{H}$ & $\mathrm{H}$ & 1.79 & 95.7 \\
\hline 40 & 3,5-Dichlorobenzoic acid & $\mathrm{COOH}$ & $\mathrm{H}$ & $\mathrm{Cl}$ & $\mathrm{H}$ & $\mathrm{Cl}$ & $\mathrm{H}$ & 1.77 & 94.7 \\
\hline 41 & 3,4,5-Trihydroxybenzoic acid & $\mathrm{COOH}$ & $\mathrm{H}$ & $\mathrm{OH}$ & $\mathrm{OH}$ & $\mathrm{OH}$ & $\mathrm{H}$ & -0.73 & 20.1 \\
\hline 42 & Salicylaldehyde & $\mathrm{CHO}$ & $\mathrm{OH}$ & $\mathrm{H}$ & $\mathrm{H}$ & $\mathrm{H}$ & $\mathrm{H}$ & 1.58 & 100.0 \\
\hline 43 & Salicylamide & $\mathrm{CONH}_{2}$ & $\mathrm{OH}$ & $\mathrm{H}$ & $\mathrm{H}$ & $\mathrm{H}$ & $\mathrm{H}$ & 1.35 & 100.0 \\
\hline 44 & Salicylhydroxamic acid & $\mathrm{CONHOH}$ & $\mathrm{H}$ & $\mathrm{OH}$ & $\mathrm{H}$ & $\mathrm{H}$ & $\mathrm{H}$ & -0.02 & 100.0 \\
\hline 45 & Phenylacetic acid & $\mathrm{CH}_{2} \mathrm{COOH}$ & $\mathrm{H}$ & $\mathrm{H}$ & $\mathrm{H}$ & $\mathrm{H}$ & $\mathrm{H}$ & 0.39 & 74.2 \\
\hline 46 & Hydrocinnamic acid & $\mathrm{CH}_{2} \mathrm{CH}_{2} \mathrm{COOH}$ & $\mathrm{H}$ & $\mathrm{H}$ & $\mathrm{H}$ & $\mathrm{H}$ & $\mathrm{H}$ & 0.45 & 79.4 \\
\hline 47 & 4-Phenylbutyric acid & $\left(\mathrm{CH}_{2}\right)_{3} \mathrm{COOH}$ & $\mathrm{H}$ & $\mathrm{H}$ & $\mathrm{H}$ & $\mathrm{H}$ & $\mathrm{H}$ & 1.73 & 98.6 \\
\hline 48 & $t$-Cinnamic acid & $\mathrm{CH}=\mathrm{CH}-\mathrm{COOH}$ & $\mathrm{H}$ & $\mathrm{H}$ & $\mathrm{H}$ & $\mathrm{H}$ & $\mathrm{H}$ & 0.30 & 70.4 \\
\hline 49 & 2-Hydroxycinnamic acid & $\mathrm{CH}=\mathrm{CH}-\mathrm{COOH}$ & $\mathrm{OH}$ & $\mathrm{H}$ & $\mathrm{H}$ & $\mathrm{H}$ & $\mathrm{H}$ & -0.10 & 48.5 \\
\hline 50 & 3-Hydroxycinnamic acid & $\mathrm{CH}=\mathrm{CH}-\mathrm{COOH}$ & $\mathrm{H}$ & $\mathrm{OH}$ & $\mathrm{H}$ & $\mathrm{H}$ & $\mathrm{H}$ & 0.01 & 56.6 \\
\hline 51 & 4-Hydroxycinnamic acid & $\mathrm{CH}=\mathrm{CH}-\mathrm{COOH}$ & $\mathrm{H}$ & $\mathrm{H}$ & $\mathrm{OH}$ & $\mathrm{H}$ & $\mathrm{H}$ & 0.06 & 58.6 \\
\hline 52 & 3,4-Dihydroxycinnamic acid & $\mathrm{CH}=\mathrm{CH}-\mathrm{COOH}$ & $\mathrm{H}$ & $\mathrm{OH}$ & $\mathrm{OH}$ & $\mathrm{H}$ & $\mathrm{H}$ & -0.37 & 36.2 \\
\hline 53 & 4-Hydroxy-3-methoxycinnamic acid & $\mathrm{CH}=\mathrm{CH}-\mathrm{COOH}$ & $\mathrm{H}$ & $\mathrm{OCH} 3$ & $\mathrm{OH}$ & $\mathrm{H}$ & $\mathrm{H}$ & -0.04 & 52.7 \\
\hline 54 & Catechol & $\mathrm{OH}$ & $\mathrm{OH}$ & $\mathrm{H}$ & $\mathrm{H}$ & $\mathrm{H}$ & $\mathrm{H}$ & 0.84 & 100.0 \\
\hline
\end{tabular}


Table 2

Modifications of transmembrane potential of pulvinar motor cells and of net $\mathrm{H}^{+}$influxes monitored in the bathing medium of pulvinar tissues of Mimosa pudica induced by various benzoic acid derivatives. For $\Delta \Psi$, calculations were made 10 min after application of the compound; +, hyperpolarization; -, depolarization. $\mathrm{Net} \mathrm{H}^{+}$influx was determined $2 \mathrm{~h}$ after application of the compound; -, outwardly directed flux.

\begin{tabular}{|c|c|c|c|c|c|c|}
\hline \multirow[t]{2}{*}{$\mathbf{N}^{\circ}$} & \multirow[t]{2}{*}{ Compound } & \multicolumn{3}{|c|}{ Membrane potential } & \multicolumn{2}{|c|}{ Inwardly $\mathbf{H}^{+}$flux } \\
\hline & & Latency (s) & $\Delta \Psi(\mathrm{mV})$ & $\mathbf{n}$ & Latency (min) & nmol $\mathbf{H}^{+}$ \\
\hline $\mathbf{0}$ & Control & - & $+1 \pm 1$ & 30 & - & $-473 \pm 63$ \\
\hline 1 & Salicylic acid & $20 \pm 7$ & $+30 \pm 6$ & 8 & $15 \pm 3$ & $641 \pm 39$ \\
\hline 2 & 2,3-Dihydroxybenzoic acid & $65 \pm 13$ & $+16 \pm 2$ & 4 & $13 \pm 3$ & $222 \pm 45$ \\
\hline 3 & 2,4-Dihydroxybenzoic acid & $75 \pm 15$ & $+11 \pm 6$ & 4 & $21 \pm 3$ & $203 \pm 31$ \\
\hline 5 & 2,6-Dihydroxybenzoic acid & $52 \pm 12$ & $+8 \pm 6$ & 5 & $25 \pm 6$ & $78 \pm 10$ \\
\hline 6 & 2-Hydroxy-3-methoxybenzoic acid & $39 \pm 8$ & $+27 \pm 8$ & 4 & $19 \pm 3$ & $305 \pm 40$ \\
\hline 10 & 2,3,4-Trihydroxybenzoic acid & $35 \pm 7$ & $-2 \pm 2$ & 3 & $16 \pm 4$ & $-75 \pm 5$ \\
\hline 11 & 2,4,6-Trihydroxybenzoic acid & $62 \pm 10$ & $+12 \pm 4$ & 4 & $14 \pm 2$ & $-150 \pm 15$ \\
\hline 14 & 2-Methoxybenzoic acid & $40 \pm 27$ & $+24 \pm 4$ & 4 & $7 \pm 4$ & $483 \pm 10$ \\
\hline 15 & Acetylsalicylic acid (Aspirin) & $76 \pm 28$ & $+40 \pm 10$ & 7 & $2 \pm 0.5$ & $-91 \pm 38$ \\
\hline 16 & 2-Acetyl benzoic acid & $90 \pm 18$ & $+23 \pm 2$ & 4 & $28 \pm 3$ & $266 \pm 17$ \\
\hline 17 & 2-Aminobenzoic acid & $60 \pm 8$ & $+14 \pm 5$ & 4 & $13 \pm 3$ & $-37 \pm 4$ \\
\hline 18 & 2-Nitrobenzoic acid & $47 \pm 8$ & $+19 \pm 7$ & 4 & $18 \pm 3$ & $451 \pm 54$ \\
\hline 19 & 2-Fluorobenzoic acid & $50 \pm 5$ & $+18 \pm 4$ & 3 & $35 \pm 4$ & $83 \pm 4$ \\
\hline 20 & 2-Chlorobenzoic acid & $20 \pm 4$ & $+38 \pm 6$ & 3 & $29 \pm 3$ & $249 \pm 28$ \\
\hline 21 & 2-Bromobenzoic acid & $30 \pm 7$ & $+26 \pm 5$ & 3 & $4 \pm 1$ & $413 \pm 10$ \\
\hline 22 & 2-Iodobenzoic acid & $15 \pm 4$ & $+34 \pm 6$ & 3 & $3 \pm 0.5$ & $653 \pm 84$ \\
\hline 24 & 2,4-Dichlorobenzoic acid & $38 \pm 4$ & $+12 \pm 4$ & 4 & $14 \pm 2$ & $773 \pm 48$ \\
\hline 26 & 2,6-Dichlorobenzoic acid & $60 \pm 5$ & $+1 \pm 1$ & 4 & $30 \pm 5$ & $86 \pm 8$ \\
\hline 27 & 2,3,5-Triiodobenzoic acid (TIBA) & $17 \pm 4$ & $+38 \pm 11$ & 5 & $5 \pm 1$ & $893 \pm 52$ \\
\hline 28 & Benzoic acid & $18 \pm 6$ & $+23 \pm 4$ & 4 & $20 \pm 5$ & $343 \pm 38$ \\
\hline 29 & $m$-Hydroxybenzoic acid & $22 \pm 11$ & $-8 \pm 4$ & 8 & $17 \pm 4$ & $66 \pm 5$ \\
\hline 30 & $p$-Hydroxybenzoic acid & $23 \pm 7$ & $-27 \pm 9$ & 7 & $10 \pm 2$ & $193 \pm 17$ \\
\hline 33 & 3-Chlorobenzoic acid & $25 \pm 7$ & $+32 \pm 7$ & 4 & $21 \pm 5$ & $225 \pm 63$ \\
\hline 35 & 3,4-Dihydroxybenzoic acid & $15+3$ & $-11 \pm 3$ & 3 & $15 \pm 7$ & $115 \pm 12$ \\
\hline 37 & 4-Hydroxy-3-methoxybenzoic acid & $45 \pm 12$ & $+5 \pm 2$ & 3 & $13 \pm 3$ & $615 \pm 42$ \\
\hline 38 & 3-Hydroxy-4-methoxybenzoic acid & $50 \pm 4$ & $+15 \pm 5$ & 4 & $13 \pm 4$ & $186 \pm 18$ \\
\hline 41 & 3,4,5-Trihydroxybenzoic acid & $30 \pm 2$ & $-2 \pm 1$ & 4 & $22 \pm 7$ & $-5 \pm 10$ \\
\hline 42 & Salicylaldehyde & $42 \pm 17$ & $+6 \pm 3$ & 5 & $28 \pm 4$ & $686 \pm 32$ \\
\hline 43 & Salicylamide & $30 \pm 7$ & $+12 \pm 2$ & 4 & $12 \pm 3$ & $313 \pm 29$ \\
\hline 44 & Salicylhydroxamic acid & $34 \pm 7$ & $+28 \pm 5$ & 7 & $8 \pm 3$ & $473 \pm 15$ \\
\hline 45 & Phenylacetic acid & $15 \pm 5$ & $+32 \pm 6$ & 3 & $16 \pm 3$ & $603 \pm 18$ \\
\hline 46 & Hydrocinnamic acid & $60 \pm 6$ & $+28 \pm 6$ & 3 & $12 \pm 3$ & $643 \pm 18$ \\
\hline 47 & 4-Phenylbutyric acid & $20 \pm 7$ & $+32 \pm 8$ & 3 & $14 \pm 3$ & $663 \pm 21$ \\
\hline 48 & $t$-Cinnamic acid & $33 \pm 12$ & $+26 \pm 9$ & 4 & $18 \pm 5$ & $634 \pm 43$ \\
\hline 49 & 2-Hydroxycinnamic acid & $72 \pm 10$ & $+4 \pm 4$ & 3 & $26 \pm 5$ & $602 \pm 21$ \\
\hline 52 & 3,4-Dihydroxycinnamic acid & $45 \pm 7$ & $-9 \pm 4$ & 3 & $12 \pm 3$ & $186 \pm 16$ \\
\hline 53 & 4-Hydroxy-3-methoxycinnamic acid & $30 \pm 8$ & $-8 \pm 5$ & 3 & $10 \pm 3$ & $782 \pm 52$ \\
\hline 54 & Catechol & - & $+1 \pm 1$ & 4 & $15 \pm 4$ & $278 \pm 45$ \\
\hline
\end{tabular}




\section{Table 3}

Modifications of net proton movement (measured by absorbance variation from the control absorbance at $495 \mathrm{~nm}$ ) and vanadate-sensitive ATPase activity in plasma membrane vesicles purified from Mimosa pudica pulvini treated with various benzoic acid (BA) derivatives used at $1 \mathrm{mM}$ concentration. Values are mean \pm SD. Number of assays are indicated in brackets and percentage of inhibition (-) or activation (+) are indicated in square brackets. Superscript letters indicated significant differences at the $5 \%$ probability level by Student-Fisher $t$ test (b-d) or values not significantly different from the control (a).

\begin{tabular}{|c|c|c|c|c|c|}
\hline \multirow{2}{*}{$\begin{array}{l}\mathbf{N}^{\circ} \\
0\end{array}$} & \multirow{2}{*}{$\begin{array}{l}\text { Compound } \\
\text { Control }\end{array}$} & \multicolumn{2}{|c|}{$\begin{array}{l}\text { Absorbance variation } \\
\left(\text { unit } \mathrm{mg} \mathrm{prot}^{-1} \mathrm{~min}^{-1} \text { ) }\right.\end{array}$} & \multicolumn{2}{|c|}{$\begin{array}{l}\text { Vanadate-sensitive ATPase activity } \\
(\text { nmol Pi mg prot }\end{array}$} \\
\hline & & $0.33 \pm 0.03(36)$ & & $336 \pm 28(30)$ & \\
\hline 1 & Salicylic acid & $0.13 \pm 0.04(6)$ & {$[-61]^{b}$} & $382 \pm 64(14)$ & {$[+14]^{\mathrm{b}}$} \\
\hline 2 & 2,3-Dihydroxybenzoic acid & $0.14 \pm 0.03(6)$ & {$[-58]^{b}$} & $293 \pm 70(10)$ & {$[-13]^{\mathrm{a}}$} \\
\hline 5 & 2,6-Dihydroxybenzoic acid & $0.03 \pm 0.01(6)$ & {$[-91]^{\mathrm{c}}$} & $315 \pm 62(10)$ & {$[-7]^{\mathrm{a}}$} \\
\hline 15 & Acetylsalicylic acic (Aspirin) & $0.22 \pm 0.05(10)$ & {$[-33]^{\mathrm{d}}$} & $274 \pm 37(6)$ & {$[-18]^{\mathrm{c}}$} \\
\hline 20 & 2-Chlorobenzoic acid & $0.24 \pm 0.06(6)$ & {$[-27]^{\mathrm{d}}$} & $280 \pm 64(8)$ & {$[-17]^{\mathrm{c}}$} \\
\hline 28 & Benzoic acid & $0.23 \pm 0.03(6)$ & {$[-30]^{\mathrm{d}}$} & $389 \pm 30(6)$ & {$[+16]^{b}$} \\
\hline 29 & $m$-Hydroxybenzoic acid & $0.31 \pm 0.09(6)$ & {$[-6]^{\mathrm{a}}$} & $394 \pm 33(6)$ & {$[+17]^{\mathrm{b}}$} \\
\hline 30 & $p$-Hydroxybenzoic acid & $0.32 \pm 0.07(6)$ & {$[-3]^{\mathrm{a}}$} & $385 \pm 68(8)$ & {$[+15]^{\mathrm{b}}$} \\
\hline 33 & 3-chlorobenzoic acid & $0.23 \pm 0.04(8)$ & {$[-30]^{\mathrm{d}}$} & $343 \pm 83(10)$ & {$[+2]^{a}$} \\
\hline 41 & 3,4,5-Trihydroxybenzoic acid & $0.25 \pm 0.08(10)$ & {$[-24]^{\mathrm{d}}$} & $241 \pm 41(14)$ & {$[-28]^{\mathrm{c}}$} \\
\hline \multirow[t]{2}{*}{48} & $t$-Cinnamic acid & $0.25 \pm 0.03(8)$ & {$[-24]^{\mathrm{d}}$} & $328 \pm 46(6)$ & {$[-2]^{\mathrm{a}}$} \\
\hline & Vanadate & $0.15 \pm 0.06$ & {$[-55]^{b}$} & $149 \pm 16(30)$ & {$[-56]^{\mathrm{d}}$} \\
\hline
\end{tabular}


Table 4

Spearman rank correlation ( $\mathrm{r}_{\mathrm{s}}$ coefficients) matrix. Significant values are denoted by asterisks associated with the $\mathrm{P}$ values : ${ }^{* * *} p<0.0001 ; * * * p<0.001 ; * * p<0.01 ; * p<0.05$.

\begin{tabular}{|c|c|c|c|c|}
\hline Variables & $\begin{array}{c}\text { Seismonasty } \\
\text { inhibition (\%) }\end{array}$ & $\begin{array}{l}\text { Membrane potential } \\
\text { variation }(\mathrm{mV})\end{array}$ & $\begin{array}{c}\text { Net } \mathbf{H}^{+} \text {influx } \\
\left(\mathbf{n m o l} \mathbf{H}^{+}\right)\end{array}$ & $\log D$ \\
\hline $\begin{array}{l}\text { Membrane potential } \\
\text { variation }(\mathrm{mV})\end{array}$ & $0.767 * * * *$ & - & - & - \\
\hline Net $\mathbf{H}^{+}$influx $\left(\mathbf{n m o l} \mathbf{H}^{+}\right)$ & $0.581 * * *$ & $0.358^{*}$ & - & - \\
\hline $\log D$ & 0.256 & 0.179 & $0.488 * *$ & \\
\hline Undissociated form (\%) & 0.135 & 0.102 & $0.449 * *$ & $0.923 * * * *$ \\
\hline
\end{tabular}




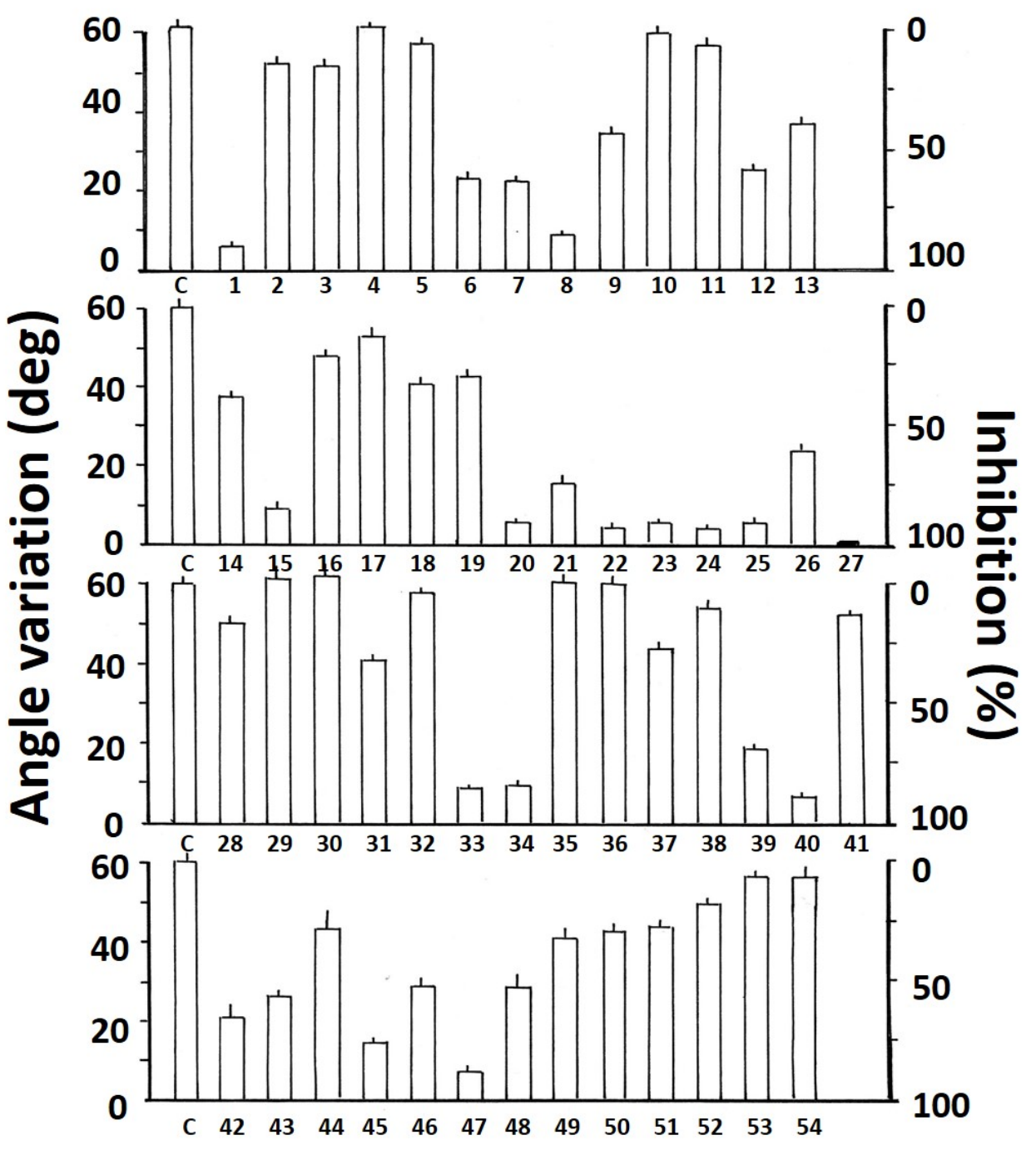

\section{Compounds as numbered in table 1}

Fig. 1. Structure - inhibition of the seismonastic reaction of the Mimosa pudica pulvinus by various phenolics assayed at $1 \mathrm{mM}$ final concentration and at $\mathrm{pH}$ 5.2. (A) Effects of various SA derivatives. (B) Effects of benzoic acid derivatives obtained through a substitution of the 2-hydroxyl group on the benzene ring. (C) Effect of benzoic acid derivatives obtained after substitution of various groups on the benzene ring. (D) Effect of phenolic derivatives obtained though modifications of the aliphatic chain bearing the carboxylic acid function. After measurement of the initial angle $\left(\alpha_{i}\right)$, the pulvini were stimulated by a touch applied on the abaxial half of the organ for $4 \mathrm{~h}$ at $1 \mathrm{~h}$ intervals. The motor reaction was monitored by measuring the variation of the angle within $10 \mathrm{~s}$ after the stimulation. $0 \%$ inhibition corresponds to a mean leaf drooping of about 60 degrees and $100 \%$ inhibition corresponds to a 0 angle variation. The experiments were carried out on 30 seedlings separated in 3 sets. Mean \pm SEM (SEM, standard error); $n=18$. Numbers of compounds used refer to the terminology in Table 1 . 


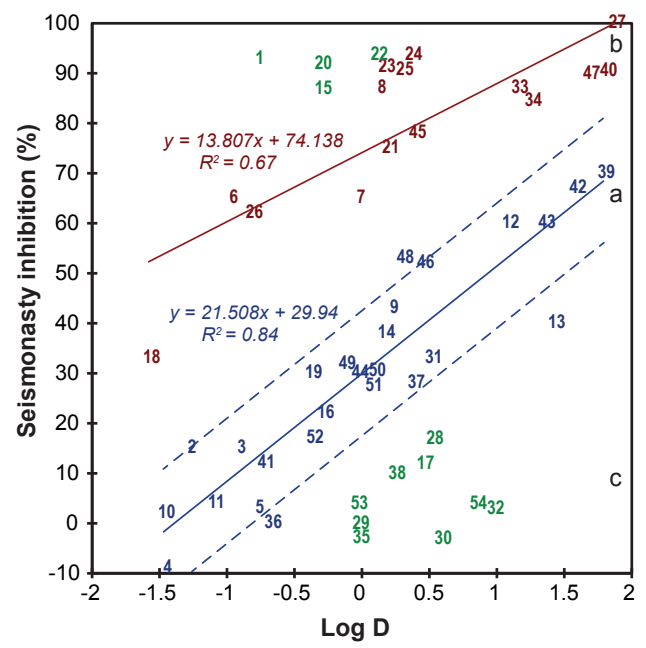

Fig. 2. Relationship between the inhibition of the seismonastic reaction of the Mimosa pudica pulvinus and the octanol/water partition coefficients (as $\log \mathrm{D})$ determined for the various phenolics assayed and located by the numbers in Table 1 . 


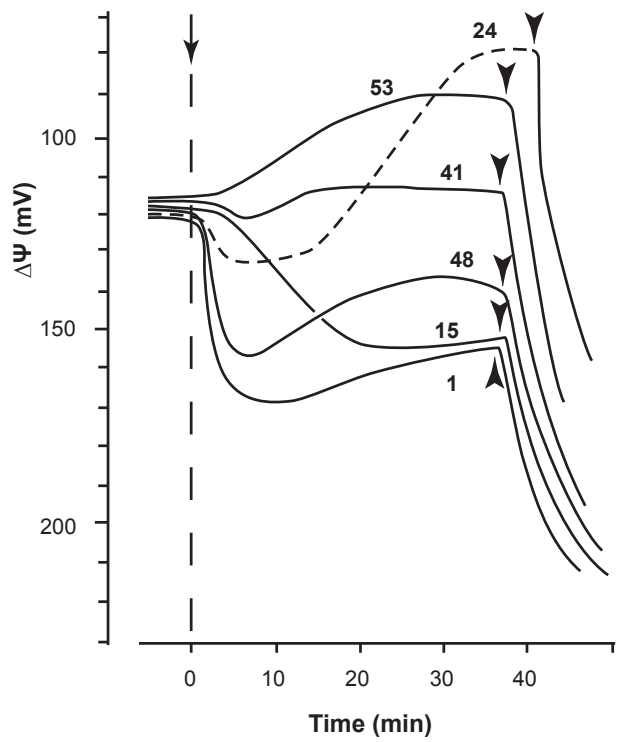

Fig. 3. Typical recordings of transmembrane potential variations in parenchyma cells of the Mimosa pudica pulvinus induced by application of salicylic acid (1), acetyl salicylic acid (15), 2,4dichlorobenzoic acid (24), 3,4,5-trihydroxybenzoic acid (gallic acid, 41), $t$-cinnamic acid (48) and 4hydroxy-3-methoxycinnamic acid (ferulic acid, 53). Compounds at $1 \mathrm{mM}$ final concentration were added at time 0 (black arrow) and $10 \mu \mathrm{M}$ fusicoccin was added at the black arrowheads. 

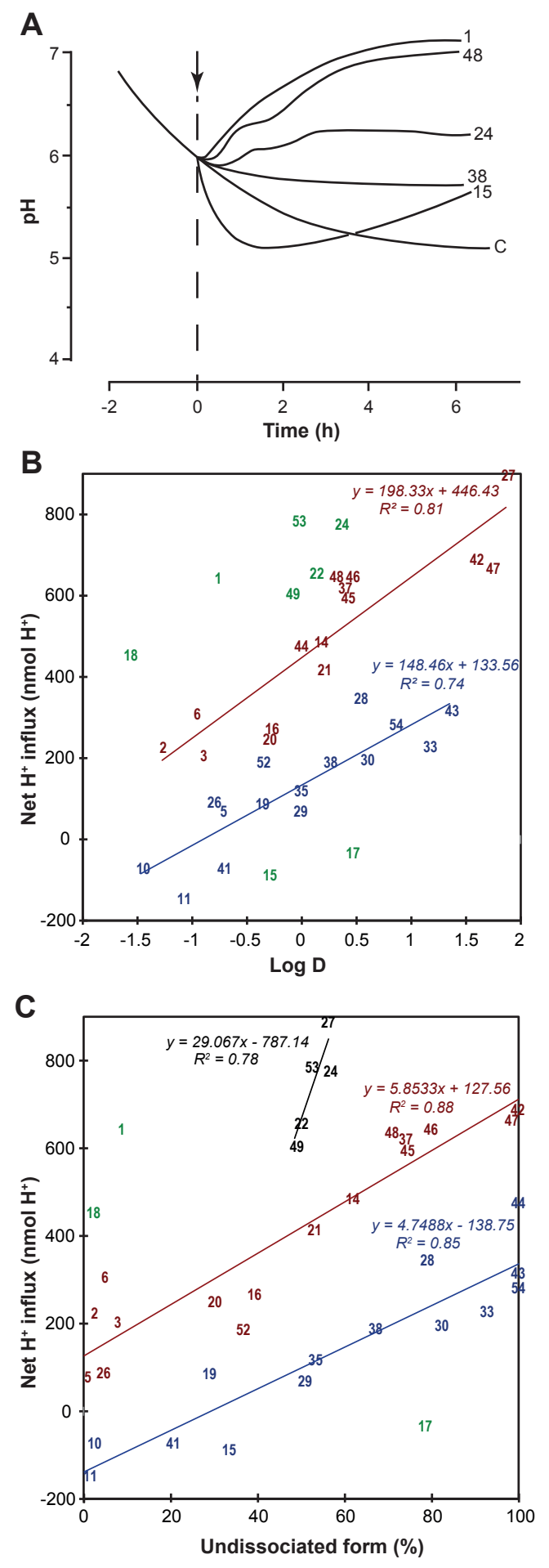

Fig. 4. Study of the net inwardly proton flux monitored in the bathing medium of Mimosa pudica pulvinar tissues supplemented with phenolics assayed and located by the numbers in Table 1. (A) Examples of representative time courses of $\mathrm{pH}$ variations monitored in the bathing medium of Mimosa pudica pulvinar tissues induced by application at $1 \mathrm{mM}$ final concentration at time 0 (black arrow) of salicylic acid (1), acetyl salicylic acid (15), 2,4-dichlorobenzoic acid (24), $t$-cinnamic acid (48). Control (c). Relationship between the net $\mathrm{H}^{+}$influx and (B) the octanol/water partition coefficients (as log D), (C) the percentage of undissociated form determined for the various phenolics assayed and located by the numbers in Table 1. 

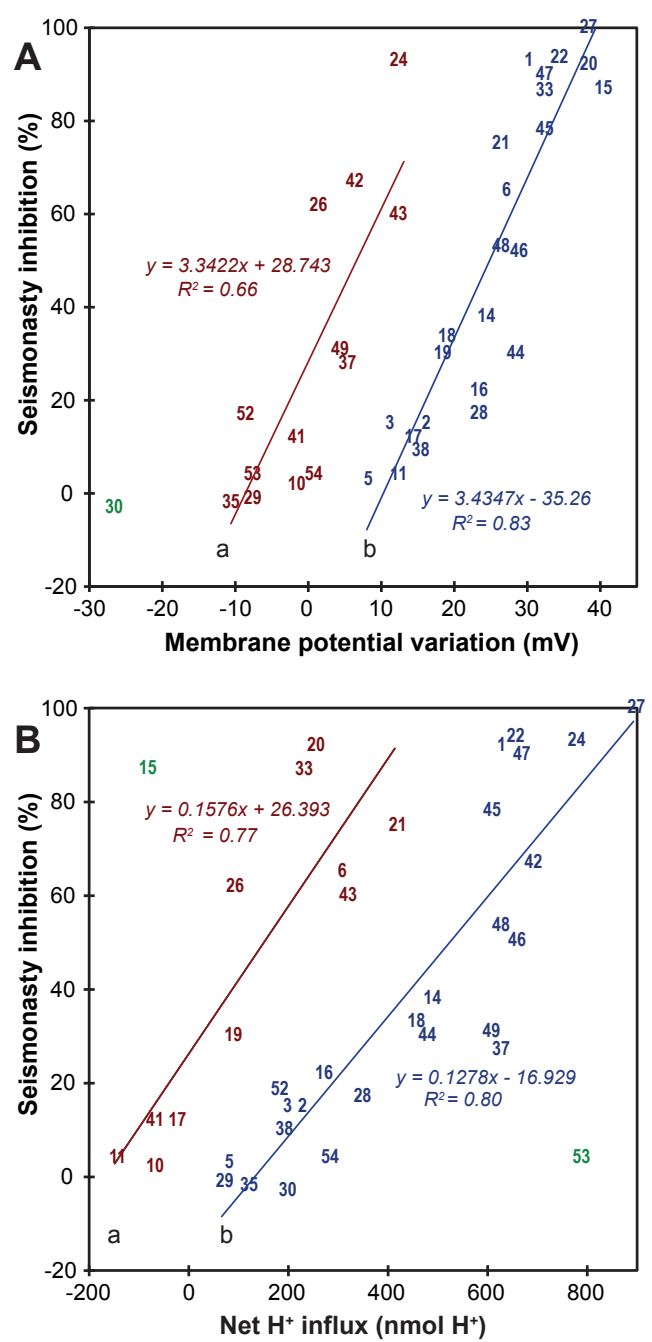

Fig. 5. Relationship between the pulvinar seismonastic inhibition and (A) the membrane potential variation induced by application of phenolics, (B) the net $\mathrm{H}^{+}$influx monitored in the bathing medium of Mimosa pudica pulvinar tissues supplemented with phenolics assayed and located by the numbers in Table 1. 


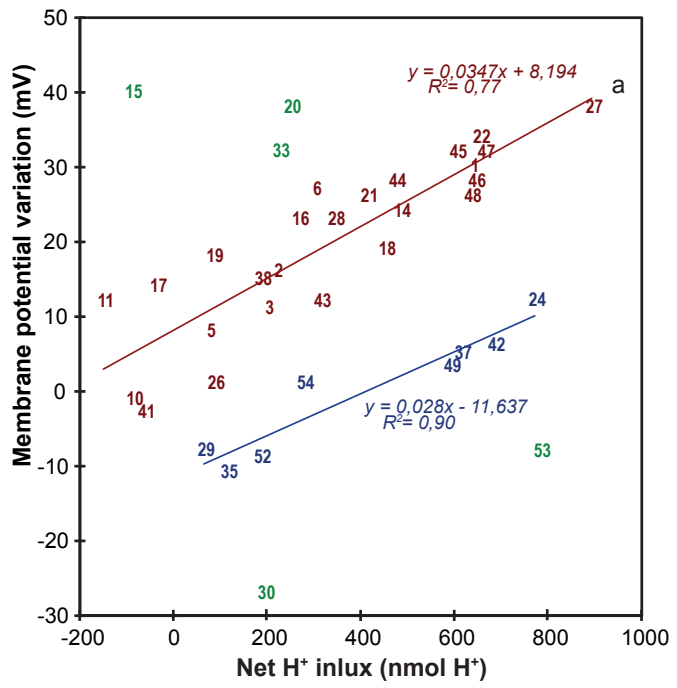

Fig. 6. Relationship between the membrane potential variation induced by application of phenolics and the net $\mathrm{H}^{+}$influx monitored in the bathing medium of Mimosa pudica pulvinar tissues supplemented with phenolics assayed and located by the numbers in Table 1 . 


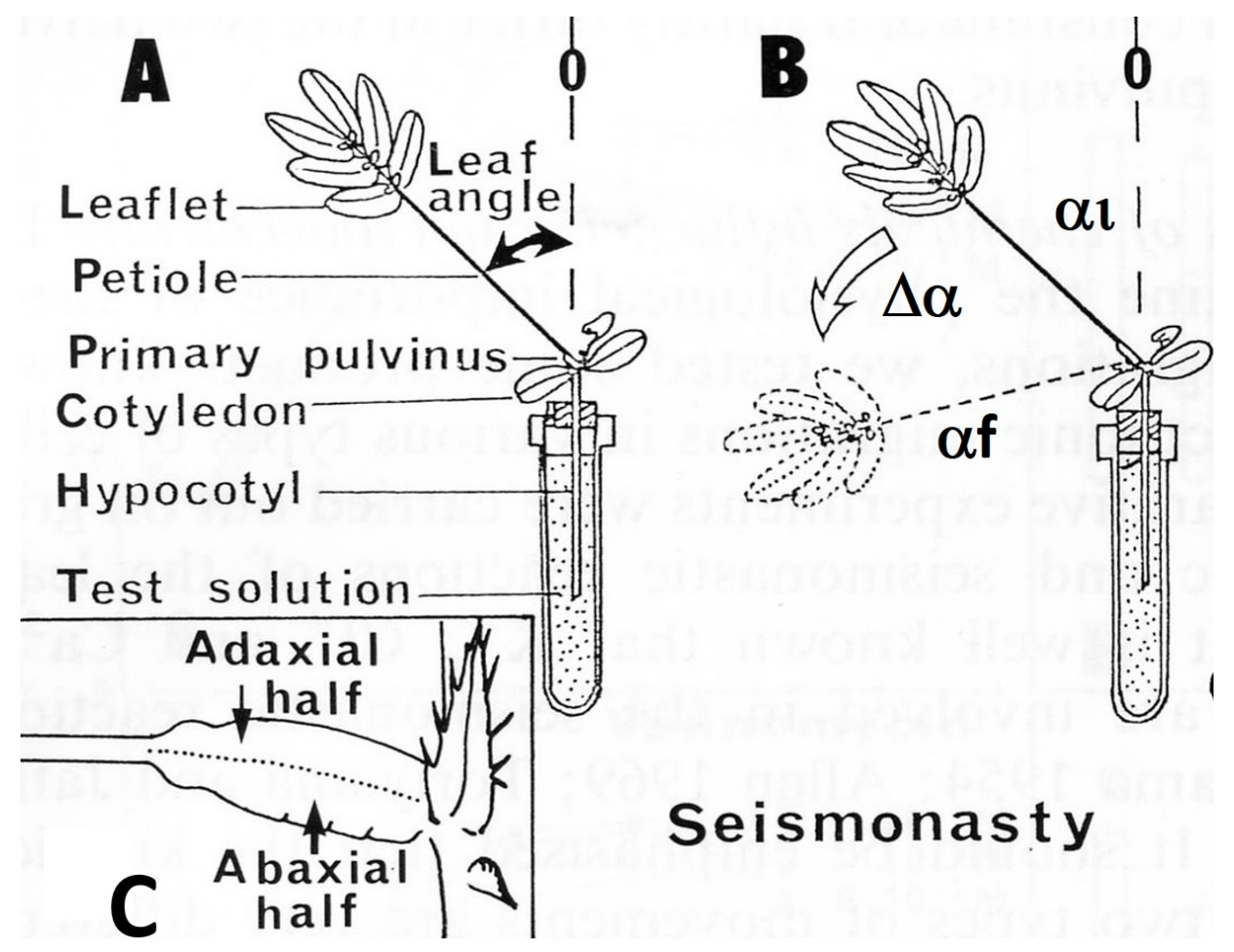

Figure 1 Supplementary data: (A) General morphology of a Mimosa pudica seedling; (B) Experimental procedure for the observation of the seismonastic movement, performed by the antagonistic action of the two halves of the primary pulvinus (C). 